\title{
Polysèmes
}

Revue d'études intertextuelles et intermédiales

\section{Le descriptif chez Ernest Hemingway : pour une ontologie moderne en littérature}

\section{Clara Mallier}

\section{(2) OpenEdition}

\section{Journals}

\section{Édition électronique}

URL : http://journals.openedition.org/polysemes/1773

DOI : 10.4000/polysemes. 1773

ISSN : 2496-4212

Éditeur

SAIT

\section{Édition imprimée}

Date de publication : 2 janvier 2007

Pagination : 147-159

ISSN : 0999-4203

\section{Référence électronique}

Clara Mallier, «Le descriptif chez Ernest Hemingway : pour une ontologie moderne en littérature », Polysèmes [En ligne], 9 | 2007, mis en ligne le 01 janvier 2007, consulté le 19 avril 2019. URL : http:// journals.openedition.org/polysemes/1773; DOI : 10.4000/polysemes.1773

Ce document a été généré automatiquement le 19 avril 2019.

Polysèmes 


\title{
Le descriptif chez Ernest Hemingway : pour une ontologie moderne en littérature
}

\author{
Clara Mallier
}

\section{Le descriptif : une « pause » visuelle}

1 La notion critique de descriptif se confond traditionnellement avec celle de description. Comme substantif, le mot "descriptif» n'a pas d'acception relevant de la critique littéraire ou esthétique dans le Robert: le seul sens dont le dictionnaire fasse état est « document qui décrit précisément au moyen de plans, schémas et légendes ».

Dans son ouvrage Introduction à l'analyse du descriptif, Philippe Hamon établit pourtant une distinction entre "descriptif » et "description » : à la seconde notion, qui évoque " une unité spécifique pourvue [...] d'une essence stable et de traits fixes", il préfère la première qui dénote "un certain effet de texte", "un lieu où se manifestent prioritairement certains modes et postures d'énonciation », " un mode d'être des textes où [...] se met en scène une utopie linguistique, celle de la langue comme nomenclature $»^{1}$.

Cependant, le descriptif ainsi défini ne peut s'actualiser que dans des descriptions: Hamon déclare que «le lecteur moyen, en général, identifie d'emblée et sans hésitation une description. Il la "découpe" aisément dans le contexte qui l'enchâsse, et il est aussi bien capable de la prélever dans un ensemble plus vaste que de la "sauter" pour courir aux péripéties et aux points névralgiques d'un récit $»^{2}$. Le descriptif se distingue donc de la description car il fait référence à un mode particulier de production de sens, alors que la notion de description désigne des textes existants ; mais les deux termes perpétuent ensemble l'opposition du descriptif et du narratif, de la description et de la narration. Selon Hamon cette opposition «fait partie [...] des évidences les plus ancrées, les plus fermement expérimentées, de notre pratique de la lecture $»^{3}$. Il entend donc "explorer les raisons de cette différenciation si évidente ", regrettant que les manuels scolaires n'éprouvent pas «le besoin de justifier cette distinction "naturelle" ». Il ne s'agit pas 
cependant pour Hamon de remettre en cause la pertinence de cette opposition : une certitude demeure, le descriptif ne peut pas s'incarner dans des textes relevant du narratif.

4 La description dans son usage traditionnel interrompt la narration des faits pour s'attarder sur un élément de décor, la physionomie d'un personnage ou l'aspect d'un paysage. Ce caractère de pause contemplative est lié à une seconde fonction essentielle de la description, la tentative de pallier l'absence d'éléments sensoriels et plus particulièrement visuels dans un récit: décrire un environnement ou une personne revient à vouloir en fournir une représentation pseudo-visuelle, qui permette au lecteur d'en élaborer une « image mentale ». Cette image mentale, cela ne fait pas de doute, n'est pas comparable à une image réelle: Sartre en explique les raisons dans son essai L'Imaginaire ${ }^{4}$. Toutefois, que la description veuille entretenir un rapport avec l'image, réelle ou mentale, est attesté par les formes descriptives qui sont fondées sur ce rapprochement: l'ekphrasis, l'hypotypose et plus généralement l'enargeia, qui, comme le rappelle Liliane Louvel dans son ouvrage L'Eil du texte, était considérée comme "vive description s'adressant à l'œil de l'âme" avant de se confondre avec l'ekphrasis, « description riche et détaillée d'un objet d'art " $^{5}$.

5 Pause dans le récit et tentative de présenter l'aspect visuel d'un décor ou personnage, la description est écriture de l'objet. On dit spontanément qu'une description «prend pour objet » telle ou telle chose, mais on pourrait aussi bien dire qu'elle constitue en objet ce dont elle parle grâce aux contours qu'elle définit par son début et sa fin, en même temps qu'elle se propose elle-même comme objet textuel.

6 Dans le cas des descriptions picturales - qu'il s'agisse d'ekphrasis, référence explicite à une œuvre d'art existante, ou d'hypotypose, simple évocation d'effets picturaux - la description fait référence à une partie du monde déjà constituée en objet par le biais de la représentation picturale: il y a donc un double mouvement d'objectification du réel, parallèle à la double médiatisation dont parle Liliane Louvel lorsqu'elle dit que "l'iconotexte est à l'interface de deux médiations [celle du texte et celle du tableau], chacune étant déjà elle-même décrochée d'un cran par rapport au réel ».

7 Cette théorie canonique du descriptif est particulièrement intéressante à confronter aux textes d'Ernest Hemingway, pour la bonne raison que ces derniers refusent de s'y conformer. Ils ne correspondent en effet ni au modèle de l'opposition narration/ description, ni à celui de la description à caractère pictural ou visuel. La résistance qu'ils offrent invite à élaborer une nouvelle conception du descriptif, qui permettra en retour de mettre en lumière la modernité de l'écriture de l'auteur.

\section{Le descriptif chez Ernest Hemingway}

Dans les textes d'Hemingway, les descriptions de lieux ne constituent quasiment jamais une pause dans le récit car l'environnement n'est mentionné que dans la mesure où il entre dans le champ de perception ou d'action des personnages. Les éléments descriptifs sont parsemés dans le texte, en alternance avec des verbes de mouvement et de perception qui indiquent la position des personnages dans leur environnement. L'antithèse narration/description est ici neutralisée, et l'on a affaire à une description d'un type particulier que Genette appelle «narrativisée » parce qu'elle devient élément du récit. Ce phénomène original est également répertorié par Helmut Bonheim qui 
distingue ce qu'il appelle "expository description ", équivalent de la description-pause, et "fused description", analogue de la description narrativisée de Genette ${ }^{6}$. Parmi d'innombrables exemples chez Hemingway, on peut citer un extrait de A Farewell to Arms ${ }^{7}$ dans lequel le narrateur relate son retour au front après une permission, avec une alternance régulière de verbes de mouvement et de verbes de perception :

We saw the town with a mist over it that cut off the mountains. We crossed the river and I saw that it was running high. It had been raining in the mountains. We came into the town past the factories and then the houses and villas and I saw that many more houses had been hit. On a narrow street we passed a British Red Cross ambulance. The driver wore a cap and his face was thin and very tanned (163, je souligne)

9 Une telle pratique montre que la catégorie du "descriptif» peut constituer une alternative critique intéressante à celle de la description, pour des raisons différentes de celles invoquées par Philippe Hamon: la notion de descriptif permet d'exprimer un caractère inchoatif, la présence d'éléments descriptifs dans un texte qui n'est pas une description. Cette distinction permet d'élargir l'étude du descriptif à des textes aux statuts divers et ainsi de repenser le rapport entre description et narration.

Revenons à l'extrait de A Farewell to Arms, qui permet d'observer une autre caractéristique du descriptif chez Hemingway, particulièrement visible dans les textes à la première personne : si description et narration sont imbriquées, c'est parce qu'elles se rapportent toutes deux à la conscience du personnage-narrateur, et que pour ce dernier, la perception de son environnement et de sa propre mobilité dans cet environnement sont intimement liées. L'intégration de la description au récit signifie que l'ordre dans lequel les choses sont décrites reflète celui dans lequel elles sont perçues par le protagoniste, le rythme du texte se faisant reflet fidèle de celui des sensations du personnage. Or, comme le narrateur donne généralement très peu d'informations sur la vie psychologique du héros, même dans les textes homodiégétiques, la conscience du personnage devient palpable dans la trame du récit au lieu de faire l'objet de commentaires ou d'analyses.

11 Le descriptif est ici non seulement narrativisé mais aussi «focalisé », porteur d'un point de vue : ce qui est décrit reflète presque toujours le regard d'un personnage, non pas tant par une description explicitement subjective que par le simple phénomène de la sélection des faits. Cela peut prendre la forme de l'alternance perception/action mentionnée précédemment ou celle d'un rapport particulier du protagoniste à son environnement. Le héros observe alors un lieu avec une grille interprétative implicite qui est fonction de ses compétences et de ses désirs particuliers : le pêcheur cherche les lieux où il pourra se procurer des sauterelles pour appât, le militaire les endroits où il sera protégé d'une attaque, le flâneur ceux où il trouvera de l'ombre et du repos; ainsi, dans un autre passage de A Farewell to Arms où le narrateur décrit une ferme, le regard que le personnage porte sur les lieux reflète sa recherche d'un ennemi potentiel :

Crossing the field, I did not know but that someone would fire on us from the trees near the farmhouse or from the farmhouse itself. I walked toward it, seeing it very clearly. The balcony of the second floor merged into the barn and there was hay coming out between the columns. The courtyard was of stone blocks and all the trees were dripping with the rain. There was a big empty two-wheeled cart, the shafts tipped high up in the rain. I came to the courtyard, crossed it, and stood under the shelter of the balcony. The door of the house was open and I went in. Bonello and Piani came in after me. It was dark inside. I went back to the kitchen. There were ashes of a fire on the big open hearth. The pots hung over the ashes, but they were empty. (215) 
12 Le type de regard que Frederic Henry porte sur la scène, que l'on retrouve en maintes occasions chez les protagonistes d'Hemingway, est qualifié par John Graham de "purposeful observation [...] the usual method employed [by Hemingway] for the apparently "incidental" presentation of concrete surroundings $"^{8}$. Sartre lui-même s'intéresse à cette technique et considère qu'elle sonne le glas de la description traditionnelle :

[...] après Hemingway, comment pourrions-nous songer à décrire ? Il faut que nous plongions les choses dans l'action : leur densité d'être se mesurera pour le lecteur à la multiplicité des relations pratiques qu'elles entretiendront avec les personnages. Faites gravir la montagne par le contrebandier, par le douanier, par le partisan, faites-la survoler par l'aviateur, et la montagne surgira tout à coup de ces actions connexes, sautera hors de votre livre, comme un diable de sa boîte. ${ }^{9}$

13 L'un des stéréotypes les plus tenaces concernant l'écriture d'Hemingway est celui de son " objectivité ", du moins à propos de ses premiers romans et de ses nouvelles les plus célèbres. Cependant, comme le fait remarquer Graham, la présentation de l'environnement n'est qu' "apparemment " incidente : il n'y a certes pas d'expression subjective explicite, mais derrière l'objectivité apparente de la description se cache - ou se révèle - la conscience du protagoniste et son rapport au monde particulier. Bien qu'il évite l'usage d'adjectifs à valeur subjective, cela ne signifie pas qu'Hemingway accorde à l'objet un statut d'autonomie ontologique.

14 Signe de ce phénomène, ses descriptions manquent souvent de détails et leurs objets finissent par se confondre d'un texte à l'autre. Ainsi les paysages d'Hemingway se ressemblent-ils tous, qu'ils se situent aux États-Unis ou en Europe : c'est particulièrement visible dans les épisodes de pêche du roman The Sun Also Rises ${ }^{10}$ et de la nouvelle «Big Two-Hearted River ${ }^{11}$, situés pourtant l'un dans le Michigan et l'autre dans la vallée de l'Irati en Espagne. On peut comparer à titre d'exemple les sous-bois décrits dans les deux textes :

There was no underbrush in the island of pine trees. The trunks of the trees went straight up or slanted toward each other. The trunks were straight and brown without branches. The branches were high above. Some interlocked to make a solid shadow on the brown forest floor.

Around the grove of trees was a bare space. It was brown and soft underfoot as Nick walked on it. This was the over-lapping of the pine needle floor, extending out beyond the width of the high branches. The trees had grown tall and the branches moved high, leaving in the sun this bare space they had once covered with shadow. Sharp at the edge of this extension of the forest floor commenced the sweet fern. ("Big Two-Hearted River")

It was a beech wood and the trees were very old. Their roots bulked above the ground and the branches were twisted. We walked on the road between the thick trunks of the old beeches and the sunlight came through the leaves in light patches on the grass. The trees were big, and the foliage was not gloomy. There was no undergrowth, only the smooth grass, very green and fresh, and the big gray trees were well spaced as though it were a park. 'This is country,' Bill said. (The Sun also Rises, 122)

15 Si l'on compare les détails concrets, on s'aperçoit que les deux sous-bois ne sont pas identiques, loin s'en faut. Les arbres ne sont pas les mêmes, des pins dans «Big TwoHearted River » et des hêtres dans The Sun Also Rises; dans le premier texte les branches sont droites ("straight ») et dans le second tordues ( "twisted ») ; le sol est fait d'aiguilles de pins dans la nouvelle, et d'herbe dans le roman. Mais il se trouve aussi de nombreuses similitudes entre les deux extraits : une absence de sous-bois (« no undergrowth », « no 
underbrush »), une douceur du contact du sol, qui est " soft underfoot » dans la pinède, et « smooth » dans la hêtraie, et surtout, analogie plus importante que les autres, une même absence de détails dans la description.

Carlos Baker a commenté le deuxième passage dans des termes qui s'appliquent tout à fait au premier :

For all the restraint, the avoidance of color-flaunting adjectives, and the plainsong sentences (five compound to one complex), the paragraph is loaded with precise observable fact: [...] One cannot say that he has been given a generalized landscape - there are too many exact factual observations. On the other hand, the uniquenesses of the place receive no special emphasis.

One recognizes easily the generic type of the clean and orderly grove, where weeds and brush do not flourish because of the shade, and the grass gets only enough light to rise to carpet-level. Undoubtedly, [...] the intent is to provide a generic frame within which the reader is at liberty to insert his own uniquenesses - as many or as few as his imagination may supply. When he has finished, it is possible to say (and we supply our own inflection for Bill Gorton's words): "This is country." 12

Cette expression, «This is country ", ne décrit rien, elle est parfaitement redondante avec la situation, mais son imprécision même permet au lecteur de se représenter tout le plaisir éprouvé par Bill Gorton : le paysage n'est pas défini par une qualité déterminée mais simplement par la réaction de plaisir qu'il provoque, celle de se trouver en présence d'une quintessence de la nature. Le parallèle entre les deux textes se poursuit d'ailleurs jusqu'ici puisque l'on trouve plus loin dans « Big Two-Hearted River » la phrase « This was good country».

La technique qui consiste à effacer les propriétés d'un objet au profit de la réaction qu'il suscite chez un personnage est employée fréquemment par Hemingway : un jugement fait alors office de description, comme lorsque Jake Barnes dit d'un hôtel où il loge « it was a nice hotel » ou d'un champagne qu'on vient de lui servir « it was amazing champagne » ( The Sun also Rises, 95 et 66): les adjectifs « nice » et « amazing ", plutôt que de donner au lecteur une idée précise de l'objet, signifient la réaction du personnage et surtout permettent au lecteur de réagir selon les limites de sa propre expérience et de son imagination en la matière. De telles descriptions semblent plates considérées isolément, mais elles prennent tout leur sens dans le contexte d'un roman, car elles offrent au lecteur la possibilité d'habiter la conscience du personnage en en inventant lui-même le contenu, à l'intérieur du cadre fixé par l'adjectif employé.

Harry Levin observe à propos des adjectifs « fine », «nice » et "good", omniprésents sous la plume d'Hemingway, qu'ils constituent des descriptions non-picturales : l'objet n'est pas décrit pour lui-même mais devient le support d'une émotion projetée par l'auteur et recréée par le lecteur, émotion fréquemment d'ordre euphorique: "Such descriptions - if we may consider them descriptions - are obviously not designed for pictorial effect. ["Beautiful"], like "fine" and "nice," or "good" and "lovely," [...] does not describe; it evaluates. It is not a stimulus but a projected response, a projection of the narrator's euphoria in a given situation $»^{13}$. Hemingway suit donc les préceptes de son mentor Ezra Pound qui déconseillait aux écrivains de tenter de rivaliser avec les peintres : "Don't be "viewy" [...]. Don't be descriptive; remember that the painter can describe a landscape much better than you can, and that he has to know a deal more about it $»^{14}$.

Refusant I'ekphrasis bien sûr, mais aussi l'hypotypose, Hemingway crée néanmoins une prose très convaincante, qui donne au lecteur l'impression d'habiter les mêmes lieux que ses personnages. Le lecteur, amené à participer à la construction du paysage, entretient 
un rapport immédiat à ce contenu, et cette immédiateté même constitue une expérience qui, paradoxalement, se rapproche de l'expérience visuelle.

21 En ce sens, on peut dire qu'Hemingway réinvente l'enargeia, cette description qui s'adresse à l'œil de l'âme, à ceci près qu'elle s'adresse chez lui à tous les sens : ainsi, dans les extraits de The Sun Also Rises et «Big Two-Hearted River» cités plus haut, les références au toucher et à la couleur sont si intimement liées qu'elles semblent synesthésiques : "There was no undergrowth, only the smooth grass, very green and fresh » ou bien « [the ground] was brown and soft underfoot as Nick walked on it » (je souligne).

L'un des éléments-clefs du caractère non-visuel de la prose d'Hemingway, et de la participation du lecteur qu'elle induit, est l'absence de détails, qui permet au lecteur d'avoir une perception plus nette d'un passage comme totalité dont tous les éléments entrent en relation. Cette technique s'observe très bien dans le premier paragraphe de $A$ Farewell to Arms, qui se rapproche plus que d'ordinaire chez Hemingway d'une véritable description parce qu'il n'est pas à proprement parler "narrativisé », bien qu'il comporte des éléments d'action (le passage des soldats sur la route) et deux mentions du sujet «we » qui rappellent que la description est porteuse d'un point de vue :

In the late summer of that year we lived in a house in a village that looked across the river and the plains to the mountains. In the bed of the river there were pebbles and boulders, dry and white in the sun, and the water was clear and swiftly moving and blue in the channels.

Troops went by the house and down the road and the dust they raised powdered the leaves of the trees. The trunks of the trees too were dusty and the leaves fell early that year and we saw the troops marching along the road and the dust rising and leaves, stirred by the breeze, falling and the soldiers marching and afterward the road bare and white except for the leaves. (3)

Ce paragraphe frappe par son abondance de répétitions, aspect célèbre de la prose d'Hemingway ; l'usage répété de la conjonction « and " par l'auteur a été abondamment commenté, mais la répétition porte ici également sur des substantifs, adjectifs et verbes, parfois sous forme de polyptote: "dust» se transforme en "dusty" avant de réapparaître sous sa forme originale.

La répétition est une façon de lier l'amont et l'aval du texte par des reprises qui sont subtiles car toujours légèrement modifiées : on trouve ainsi « the leaves of the trees » puis "the trunks of the trees", "down the road» puis «along the road", «the leaves fell early " puis « leaves, stirred by the breeze, falling »... Chacune des deuxièmes occurrences contient un élément nouveau en même temps qu'un élément répété : ainsi, le texte superpose à son déroulement successif un parcours par boucles qui reprend les éléments déjà mentionnés. Cette façon de lier les différents moments du texte interdit une perception linéaire de la description, et produit une impression de simultanéité associée d'ordinaire à la perception visuelle.

On remarque aussi que l'adjectif « white » qualifie à la fois les galets du cours d'eau et la route : or, la route et la rivière sont parallèles dans le paysage, et cet adjectif commun souligne, en même temps que leur parallélisme physique, leur parenté métaphorique: toutes deux sont des voies de passage, l'une pour l'eau, symbole de vie, et l'autre couverte de poussière, signe de stérilité qui est mentionné trois fois - pour les soldats, symboles de guerre et de mort.

26 L'absence de détail contribue à créer cet effet d'unité puisque l'attention du lecteur n'est pas détournée par la présentation minutieuse d'un aspect du paysage au détriment d'un 
autre. De ce fait, le lecteur est amené à percevoir pleinement l'interrelation des éléments du texte, non seulement au niveau des mots répétés et des parallèles symboliques mais aussi au sujet des forces de mouvement qui se rencontrent à travers la poussière qui s'élève, les feuilles qui tombent, et les soldats qui avancent. La perception du lien entre les divers éléments du texte explique aussi l'absence de tropes: leur présence n'est pas nécessaire puisque le sens ne se construit pas localement dans la richesse d'une image, mais globalement dans le rapport qu'entretiennent les phrases et les éléments du paysage.

On peut illustrer cette pratique par un deuxième exemple, extrait de la nouvelle «In Another Country ${ }^{15}$, qui, comme A Farewell to Arms, s'ouvre sur une description presque traditionnelle au sens où elle n'est pas intégrée au récit - sinon de façon minimale par l'expression "it was pleasant along the streets ", qui suggère un embryon de narration. Comme la précédente, elle reflète cependant un point de vue de personnage, refuse les détails et crée une impression de simultanéité grâce à l'usage de la répétition :

In the fall the war was always there, but we did not go to it anymore. It was cold in the fall in Milan and the dark came very early. Then the electric lights came on, and it was pleasant along the streets looking in the windows.

There was much game hanging outside the shops, and the snow powdered in the fur of the foxes and the wind blew their tails. The deer hung stiff and heavy and empty, and small birds blew in the wind and the wind turned their feathers. It was a cold fall and the wind came down from the mountains. (206-210)

Le paragraphe contient les réseaux de répétition suivants : « in the fall / in Milan / in the windows / in the fur / in the wind »; « it was cold / it was pleasant / it was a cold fall»; «the wind blew their tails / small birds blew in the wind / the wind turned their feathers » / «the wind came down from the mountains ». Le rythme du passage est très travaillé, ainsi qu'en atteste par exemple la suite d'anapestes « [i]t was cold in the fall in Milan ». Comme il le fait souvent, Hemingway reprend dans la dernière phrase plusieurs des éléments qui ont été répétés tout au long du texte, en les modifiant et en les associant : il passe de « in the fall » et « it was cold in the fall » à « it was a cold fall », puis il rementionne "the wind", si bien que la dernière phrase paraît nouer les fils de toutes les précédentes.

La conclusion du passage fait référence à des perceptions d'un ordre tactile (le vent et le froid automnal) et non visuel : cependant, plusieurs critiques ont qualifié cet extrait de "pictural » ${ }^{16}$. Cela s'explique par le fait que le texte se donne comme expérience simultanée et synesthésique: il est pauvre en détails visuels mais donne une telle impression de réalité qu'il «fait voir » la scène de façon plus immédiate que s'il l'avait dépeinte en termes picturaux. Il en va de même du paragraphe initial de A Farewell to Arms qui a été décrit comme "a highly visual passage » par un critique, et comme "a highly descriptive vignette $»$ par un autre ${ }^{17}$.

Pour revenir à "In Another Country", on peut ajouter que cette description apparemment neutre contient aussi des symboles liant guerre, froid et mort ; toutefois, ce ne sont pas des symboles traditionnels au sens où leur présence est pleinement justifiée dans l'histoire : pour être symboliques, ils n'en restent pas moins pertinents au niveau littéral dans le contexte où ils apparaissent. On a ici affaire à ce que David Lodge appelle des métaphores métonymiques, des détails qui appartiennent au contexte de la diégèse et sont donc de nature métonymique, mais auxquels leur parenté avec des thèmes évoqués dans l'œuvre fait jouer un rôle de métaphore ${ }^{18}$. Et c'est précisément l'usage de la répétition qui permet d'associer de façon subliminale le vent, la rigidité cadavérique des 
animaux suspendus, le froid ambiant et la guerre qui, bien que les protagonistes n'y aillent plus, sévit toujours.

31 Le descriptif chez Hemingway n'est pas une écriture de l'objet: il est le lieu privilégié d'une expression du rapport entre sujet et objet, à un double niveau. Au sein du texte tout d'abord, le paysage objet de la description n'est jamais constitué en dehors de sa perception par un personnage, et jamais dépeint avec précision. Ce rapport se retrouve ensuite dans l'acte de lecture, car s'il est vrai que tout texte, notamment littéraire, dépend de son lecteur pour exister, cela est particulièrement vrai des écrits d'Hemingway où, parce que la description est fréquemment "évaluative", un investissement particulièrement fort du lecteur est requis pour que l'univers du texte prenne vie.

Le monde du texte se construit donc pour le lecteur en même temps que la conscience du personnage qui habite ce monde: les deux adviennent dans une contemporanéité parfaite, notamment dans les œuvres de jeunesse d'Hemingway, celles où l'on rencontre très peu d'informations sur la psychologie des personnages, et où le descriptif constitue le principal moyen d'accès pour le lecteur à la conscience du protagoniste.

Une telle écriture évoque les théories des phénoménologues et notamment de MerleauPonty, pour qui «le monde n'est pas un objet dont je possède par devers moi la loi de constitution, il est le milieu naturel et le champ de toutes mes pensées et de toutes mes perceptions [...]. Il n'y a pas d'homme intérieur, l'homme est au monde, c'est dans le monde qu'il se connaît $»^{19}$.

Si le descriptif chez Hemingway quitte le domaine de l'objet, champ privilégié de la description classique, c'est pour se faire point d'articulation d'une relation entre le personnage et le monde de la diégèse d'une part, entre le lecteur et le texte d'autre part. Ce nouvel usage de la fonction descriptive est approprié à l'expression d'une ontologie moderne : il montre que le sujet ne peut exister sans le champ phénoménal dans lequel il s'inscrit, et corrélativement que les objets mondains n'ont pas d'existence autonome hors d'une conscience qui les perçoive.

Hemingway a maintes fois proclamé son envie d'être peintre; et pourtant, c'est en renonçant à rivaliser avec l'image visuelle que son écriture descriptive parvient à créer l'expérience de lecture la plus immédiate. Aux antipodes de la description traditionnelle du roman réaliste, qui, tournée vers l'objet, reflète une conception positiviste de l'univers et de l'homme, l'écriture descriptive chez Hemingway devient véritable expression d'un être-au-monde.

\section{NOTES}

1. Philippe Hamon, Introduction à l'analyse du descriptif, Paris : Hachette, 1981, 5 et 6 .

2. Ibid., 40. Cette idée apparaît également dans l'article du même auteur "Qu'est-ce qu'une Description? », Poétique n 12 (1972), 465-485 : « Le lecteur reconnaît et identifie sans hésiter une description : cela "tranche" sur le récit, le récit "s'arrête", le décor "passe au premier plan" etc. ", voir 465 .

3. Philippe Hamon, Introduction à l'analyse du descriptif, op. cit., 42. 
4. Jean-Paul Sartre, L'Imaginaire (1940), Paris : Gallimard, coll. « Folio essais », 1986.

5. Louvel, Liliane, L'Fil du texte. Texte et image dans la littérature de langue anglaise, Toulouse : PU du Mirail, 1998, 71-72.

6. Helmut Bonheim, The Narrative Modes: Techniques of the Short Story, Cambridge: D. S. Brewer, 1982, 24, et Gérard Genette, Nouveau Discours du récit, Paris : Éditions du Seuil, coll. « Poétique », 1983,24 .

7. Ernest Hemingway, A Farewell to Arms (1929), New York: Simon and Schuster, coll. « Scribner Paperback Fiction », 1995.

8. John Graham, «Ernest Hemingway: The Meaning of Style », in Modem Fiction Studies VI, Winter 1960-1961, 298-313, voir 303.

9. Jean-Paul Sartre, «Situation de l'écrivain en 1947 », in Situations II. Qu'est-ce que la littérature? (1948), Paris : Gallimard, coll. « Folio Essais », 1986, 287.

10. Ernest Hemingway, The Sun Also Rises (1926), New York: Simon and Schuster, coll. « Scribner Paperback Fiction », 1995.

11. Hemingway, "Big Two-Hearted River ", in The Complete Short Stories of Ernest Hemingway, The Finca Vigia Edition, New York : Simon and Shuster, coll. Scribner Paperback Fiction, 1998.

12. Carlos Baker, Hemingway: The Writer as Artist (1952), Princeton, NJ: Princeton UP, 1972, 51.

13. Harry Levin, "Observations on the Style of Ernest Hemingway », in Kenyon Review XIII, Autumn 1951, 581-609, voir, 597.

14. Literary Essays of Ezra Pound, T.S. Eliot (ed.), New York: New Directions, 1968, 6.

15. Hemingway, "In Another Country ", in The Complete Short Stones of Ernest Hemingway, op. cit., 206-210, voir 206.

16. Voir notamment T.L. Gaillard qui associe ce paragraphe à la peinture de Chardin et le décrit comme « a striking still life in the trompe l'œil tradition » : « Hemingway's Debt to Cézanne: New Perspectives ", Twentieth Literature: A Scholarly and Critical Journal (Hofstra University, Hempstead, New York), vol. XLV, n 1 (Spring 1999), 65-78, voir 76.

17. T.L. Gaillard, op. cit., 70, et J.L. Plath, « Fishing for Tension: The Dynamics of Hemingway's "Big Two-Hearted River" ", North Dakota Quarterly, vol. LXII, n² 2 (1995), 159-165, voir 161.

18. Lodge a lui-même appliqué cette idée à Hemingway en disant que «by drawing our attention [...] to similarities rather than contiguities [Hemingway makes] an apparently metonymic style [...] serve the purposes of metaphor ». Cf. The Modes of Modem Writing: Metaphor, Metonymy and the Typology of Modern Literature, Ithaca, NY: Cornell UP, 1977, 159.

19. Maurice Merleau-Ponty, Phénoménologie de la perception (1945), Paris : Gallimard, coll. « Tel », 1999, v.

\section{INDEX}

oeuvrecitee Farewell to Arms (A), Big Two-Hearted River, Sun Also Rises (The), In Another Country 